ALVES, B.G., SILVA, T.H. e IGARASI, M.S. Manejo de ordenha. PUBVET, Londrina, V. 7, N. 6, Ed. 229, Art. 1514, Março, 2013.

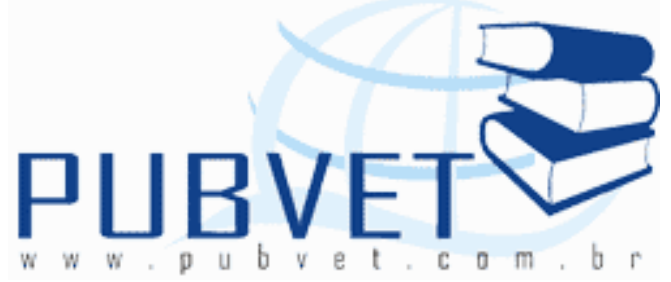

PUBVET, Publicações em Medicina Veterinária e Zootecnia.

\title{
Manejo de ordenha
}

Bruna Gomes Alves ${ }^{1}$, Thiago Henrique da Silva ${ }^{2}$, Maurício Scoton Igarasi ${ }^{3}$

${ }^{1}$ Graduando do curso de Medicina Veterinária da Universidade Federal de Uberlândia, Uberlândia/MG, e-mail: alvesbg@vet.ufu.br

${ }^{2}$ Graduando do curso de Medicina Veterinária da Universidade Federal de Uberlândia, Uberlândia/MG, e-mail: silvath@vet.ufu.br

${ }^{3}$ Professor da disciplina de Bovinocultura da Universidade Federal de Uberlândia, Faculdade de Medicina Veterinária, Uberlândia/MG,

e-mail:mauricio@famev.ufu.br

\section{Resumo}

O manejo de ordenha é fundamental na qualidade e quantidade do leite produzido, envolvendo fatores de bem estar animal, de saúde de úbere, de higienização na ordenha, e do processo de armazenamento e na conservação do leite. Animais estressados são ineficientes e comprometem a qualidade do leite, devido a efeitos hormonais que influenciam na fisiologia da lactação. A saúde do úbere é condicionante para a produção de leite com qualidade, respondendo na composição de sólidos totais e de contagem de células somáticas. A higienização da ordenha é a garantia do produto com o mínimo de contaminação para a indústria, assim como refletindo na saúde do úbere. Os procedimentos de armazenamento e conservação garantiram a maior eficiência de produção industrial de produtos lácteos. O objetivo dessa revisão 
ALVES, B.G., SILVA, T.H. e IGARASI, M.S. Manejo de ordenha. PUBVET, Londrina, V. 7, N. 6, Ed. 229, Art. 1514, Março, 2013.

é abordar os assuntos importantes referentes ao manejo de ordenha visando a produção de leite de qualidade.

\title{
Milking routine
}

\begin{abstract}
Milking routine is decisive process in milk yield and quality, evolving factors as wellfare, udder health, hygienic for milking, and milk preservation and storage. Stress cows are inefficient and decrease the quality milk, due to the effect of some hormones influence in lactation physiology. The udder health is conditioning factor critical to yield and quality milk, responsible for total solids and somatics cell count. Hygienic methods during the milking avoid contamination of environment. Good conditions of preservation and storage, assuring the efficiency in industrial process of high quality milk products. The objective this review was approach the importance of appropriate management around milking for a high production and quality of milk.
\end{abstract}

\section{FISIOLOGIA DA LACTAÇÃO E PRODUÇÃO DO LEITE}

O desenvolvimento da glândula mamária se inicia na fase embrionária em todas as espécies mamárias. No feto bovino ocorre um espessamento da ectoderme nas duas faces do abdômen do animal, ao passo que as linhas mamárias são visíveis após cerca de 40 dias. Estas linhas crescem e formamse os ramos mamários, e aos três meses os canais dos tetos podem ser vistos, sendo os alvéolos as últimas estruturas a serem formadas.

Após o nascimento até os três meses de idade, ocorre o chamado crescimento isométrico da glândula mamária, que é desenvolvido ao mesmo tempo de crescimento das outras partes do corpo. A partir dos três meses de idade até a puberdade do animal, este crescimento passa a ser alométrico, e as taxas de desenvolvimento da glândula mamária podem chegar até 2 a 4 
ALVES, B.G., SILVA, T.H. e IGARASI, M.S. Manejo de ordenha. PUBVET, Londrina, V. 7, N. 6, Ed. 229, Art. 1514, Março, 2013.

vezes mais rápidas do que as taxas de desenvolvimento dos outros órgãos do animal (TUCKER, 1987; SEJRSEN \& PURUP, 1997) (Figura 1)

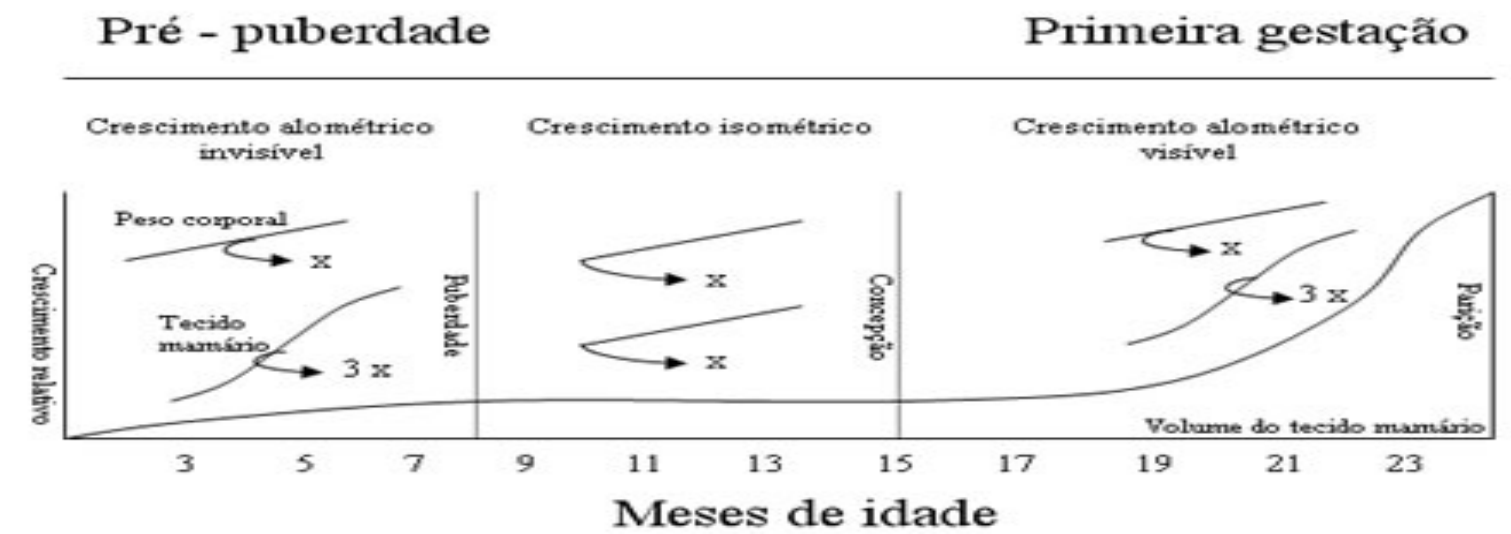

Figura 1: Crescimento e desenvolvimento mamário

O úbere é a glândula mamária das vacas, localizado na região inguinal e composto por um grande número de células responsáveis pela secreção do leite. É dividido em quatro quartos, sendo os anteriores responsáveis pela produção de aproximadamente $40 \%$ do leite e os $60 \%$ restantes produzidos pelos posteriores.

O leite é drenado dos ductos principais para a cisterna da glândula e desta passa para a cisterna da teta, onde pode ser armazenado e cerca de $80 \%$ da produção de leite em um úbere cheio de uma vaca leiteira é armazenado na região alveolar entre as ordenhas (BRUCKMAIER et al. 1994). A cisterna da glândula comunica-se com a cisterna do teto através de uma crista circular (ânulo) que contém uma veia e algumas fibras de musculatura lisa. Esta, por fim, comunica-se com o exterior por uma abertura estreita no final do teto, chamado de ducto papilar (canal do teto) que se abre no óstio papilar que dispõe de fibras musculares lisas. A estrutura primária responsável pela retenção do leite é um esfíncter muscular que rodeia o canal da teta.

No adulto, o ciclo de lactação pode ser dividido em mamogênese, lactogênese, galactopoiese e involução. Cada uma destas fases é caracterizada por íntimo controle hormonal. Três categorias de hormônios estão envolvidas: 
ALVES, B.G., SILVA, T.H. e IGARASI, M.S. Manejo de ordenha. PUBVET, Londrina, V. 7, N. 6, Ed. 229, Art. 1514, Março, 2013.

os hormônios reprodutivos (estrogênio, progesterona, prolactina e oxitocina) agem diretamente sobre a glândula mamária; os hormônios metabólicos (GH, corticosteróides, hormônios da tireóide, insulina e hormônios gastrintestinais) e finalmente, as hormônios expressados pela própria glândula, que incluem a prolactina, o GH e a leptina. Como revisado por Chillard et al. (2001) a leptina é um hormônio sintetizado pelo tecido adiposo mas também pode ter sua síntese pela glândula mamária.

Hormônios metabólicos, fatores de crescimento e prolactina são necessários para o desenvolvimento normal da glândula mamária além da importância especial para os hormônios esteróides sexuais (LAMOTE et al. 2004). Ao longo da gestação, a proliferação do epitélio mamário é dependente do estrógeno e da progesterona, apesar dos receptores específicos para estes hormônios serem expressos em baixos níveis (SHAMS et al. 2003). Do $3^{\circ}$ ao 50 mês, há maior ação do estrógeno, GH e glicocorticóides que, pelo estímulo de IGF-1 (fator de crescimento semelhante à insulina) permite o alongamento dos ductos mamários e a substituição dos adipócitos pelos alvéolos mamários. Ao final do 60 mês, além dos hormônios anteriormente citados podemos observar a atuação da prolactina e da progesterona que tem por função estimular extensivamente o desenvolvimento alveolar. Como descrito por Tucker (2000) não ocorre nenhuma atividade mamogênica na ausência de GH e prolactina.

Da estimulação pelo tato até o aumento da pressão intramamária transcorrem 30 a 60 segundos. Esta ação hormonal tem uma curta duração, de 5 a 7 minutos, daí a importância de colocar as teteiras o mais rápido possível após ter ocorrido o estímulo, caso contrário o efeito hormonal desaparece, deixando leite residual. 
ALVES, B.G., SILVA, T.H. e IGARASI, M.S. Manejo de ordenha. PUBVET, Londrina, V. 7, N. 6, Ed. 229, Art. 1514, Março, 2013.

\section{A PREOCUPAÇÃO COM A QUALIDADE DO LEITE}

\subsection{A INSTRUÇÃO NORMATIVA No 62}

O controle de qualidade do leite começa na propriedade, pois a Instrução Normativa No 62 do Ministério da Agricultura, Pecuária e Abastecimento (MAPA) determina que, pelo menos uma vez por mês, amostras do leite de cada propriedade devem ser enviadas pela indústria para serem analisadas na Rede Brasileira de Laboratórios de Controle de Qualidade do Leite (RBQL). Os resultados das análises são entregues a cada produtor, assim ele fica sabendo o que deve fazer para eliminar o problema encontrado. As análises realizadas no leite são:

- Contagem Bacteriana Total (CBT);

- Contagem de Células Somáticas (CCS);

- Determinação dos teores de gordura, lactose, proteína, sólidos totais e sólidos desengordurados;

- Pesquisa de resíduos de antibióticos;

- Pesquisa de indicadores de fraudes e adulterações.

\section{-Contagem Bacteriana Total (CBT)}

A contagem bacteriana total (CBT) indica a contaminação do leite por bactérias. Quanto menor a contagem, maior rigor higiênico existiu nas etapas de obtenção do leite. A IN no 62 preconiza para o ano de 2012 uma CBT de $10.000 \mathrm{UFC} / \mathrm{mL}$.

\section{-Contagem de Células Somáticas (CCS)}

A contagem de células somáticas (CCS) é um critério mundialmente utilizado por indústrias, produtores e entidades governamentais tanto para o monitoramento de mastite em nível individual e de rebanhos, quanto para a 
ALVES, B.G., SILVA, T.H. e IGARASI, M.S. Manejo de ordenha. PUBVET, Londrina, V. 7, N. 6, Ed. 229, Art. 1514, Março, 2013.

avaliação da qualidade do leite, em que a IN no 62 preconiza valores demonstrados na Tabela 1 a seguir:

Tabela 1. Valores de Contagem de Células Somáticas de acordo com a IN n०62.

\begin{tabular}{|l|lr|lr|l|}
\hline $\begin{array}{l}\text { Período de } \\
\text { Vigência }\end{array}$ & $\begin{array}{l}\text { De 01/01/2012 até } \\
30 / 06 / 2014\end{array}$ & $\begin{array}{l}\text { De 01/07/2014 até } \\
30 / 06 / 2016\end{array}$ & $\begin{array}{l}\text { partir de } \\
01 / 07 / 2016\end{array}$ \\
\hline CCS/mL & 480.000 & 400.000 & 360.000 \\
\hline
\end{tabular}

As células somáticas do leite são compostas basicamente por leucócitos originários do sangue e por células epiteliais de descamação. Após a invasão bacteriana da glândula mamária, ocorre rápido aumento da CCS do quarto infectado, sendo que o principal fator que afeta a CCS é a ocorrência de uma infecção intramamária (IIM).

\section{- Resíduos}

Os resíduos de antibióticos e adulterações podem ser encontrados no leite e o mesmo deve ser descartado. Para tanto, deve-se obedecer ao período de carência (descarte do leite) sugerido pelos fabricantes de cada um dos antibióticos e vale lembrar que outros produtos utilizados nos animais e na limpeza de equipamentos podem estar presentes no leite. É o caso dos vermífugos, carrapaticidas, inseticidas, desinfetantes e detergentes. O produtor deve estar atento, de modo a evitar os resíduos desses produtos no leite. 
ALVES, B.G., SILVA, T.H. e IGARASI, M.S. Manejo de ordenha. PUBVET, Londrina, V. 7, N. 6, Ed. 229, Art. 1514, Março, 2013.

\section{- Gordura e Proteína}

A maioria dos países iniciou o pagamento ao leite pela composição, por seu teor de gordura. Isso aconteceu porque a determinação do teor de gordura era relativamente fácil e, além disso, porque a manteiga naquela época era um dos principais derivados lácteos fabricados em nível mundial. A situação hoje em dia tem mudado pela própria utilização a nível mundial de leite e também porque, atualmente, os produtos com alto teor de gordura têm sofrido uma redução na demanda. Por isso, alguns países pioneiros no setor leiteiro, como é o caso da Holanda e da Dinamarca, já há três décadas iniciaram o pagamento também pelo teor protéico, considerando que pelo destino dado ao leite, era básico considerar este parâmetro.

No caso dos países onde uma grande porcentagem do leite se destina à elaboração de queijos, leite em pó, caseína ou caseinatos, é importante o pagamento por um sistema que contemple o conteúdo protéico.

$\mathrm{Na}$ maioria dos países onde esta modalidade - pagamento do leite pelo teor protéico - foi incorporada, a consideração do teor de gordura que era o parâmetro tradicional continua sendo feita, em que o limite mínimo estipulado pela IN no 62 é de 3,0g de gordura $/ 100 \mathrm{~g}$ de leite, e para proteína ficou de $2,9 \mathrm{~g} / 100 \mathrm{~g}$. Outro fator que tem contribuído para que o pagamento do leite pelo conteúdo protéico seja uma realidade em vários países é a tecnologia desenvolvida em termos de instrumentos que avançou muito, sendo mais fácil e precisa a sua determinação.

A implantação de um Sistema de Pagamento pela Qualidade vai além de estabelecer os parâmetros e valores a serem usados para a bonificação da produção. É fundamental que se tenha uma estrutura capaz de garantir a correta coleta das amostras na propriedade, assim como o seu envio para os laboratórios. E este ponto é essencial, pois garante a confiabilidade e imparcialidade dos resultados que serão utilizados na composição da bonificação pela qualidade. 
ALVES, B.G., SILVA, T.H. e IGARASI, M.S. Manejo de ordenha. PUBVET, Londrina, V. 7, N. 6, Ed. 229, Art. 1514, Março, 2013.

\section{- Refrigeração do Leite}

A refrigeração na propriedade leiteira é um dos grandes fatores contribuintes para a qualidade do leite. Quanto mais rápido for reduzida a temperatura, melhor será a conservação do leite. Para isto, utilizam-se tanques de expansão, que oferecem melhores condições para um acelerado resfriamento.

Os tanques de refrigeração por expansão direta devem ter capacidade mínima de armazenar a produção de acordo com a estratégia de coleta e deve permitir refrigerar o leite até temperatura igual ou inferior a $4^{\circ} \mathrm{C}$ (quatro graus Celsius) no tempo máximo de $3 \mathrm{~h}$ (três horas) após o término da ordenha, independente da sua capacidade;

Em se tratando de tanque de refrigeração por imersão, ser dimensionado de modo tal que permita refrigerar o leite até temperatura igual ou inferior a $7^{\circ} \mathrm{C}$ (sete graus Celsius) no tempo máximo de 3h (três horas) após o término da ordenha, independentemente de sua capacidade.

\section{COMO CONSEGUIR PRODUZIR LEITE DE QUALIDADE}

\subsection{CHEGADA DOS ANIMAIS NA SALA DE ESPERA}

\section{-Condução dos Animais}

Para que o processo da ordenha tenha sucesso, todos os procedimentos que ocorrem anteriormente à entrada dos animais na sala de ordenha são de extrema importância. Antes de buscar as vacas, sejam no pasto, ou no confinamento o funcionário deve verificar se a instalação está preparada corretamente para recebê-las, checando se está tudo funcionando adequadamente, como energia elétrica, água, porteiras, equipamentos de ordenha, produtos de limpeza e desinfecção etc. 
ALVES, B.G., SILVA, T.H. e IGARASI, M.S. Manejo de ordenha. PUBVET, Londrina, V. 7, N. 6, Ed. 229, Art. 1514, Março, 2013.

A condução das vacas deve ser feita com tranquilidade, sem gritos ou ferrões. O ideal é que as vacas andem para o local voluntariamente e para isso, a condução deve ser realizada preferencialmente sempre pela mesma pessoa e de preferência no mesmo horário. Considera-se que a distância entre o piquete mais distante e a sala de ordenha não exceda $150 \mathrm{~m}$, como também para os bebedouros. Se as vacas andarem muito, consumirão energia que poderia ser utilizada para a produção de leite.

A condução do lote fica mais fácil quando se conhece a vaca líder, trabalhando a movimentação do rebanho a partir dela. Estimulando o deslocamento da líder, estimularemos as outras vacas a acompanhá-la, mantendo um bom ritmo de deslocamento, sem correr e sem parar, até chegar ao local da ordenha. Ao chegar ao local de ordenha, acomode as vacas no curral ou na sala de espera e espere alguns minutos, para que descansem, antes de iniciar as outras atividades.

Após a correta condução e acomodação das vacas no curral ou na sala de espera, certifique-se novamente se está tudo pronto para iniciar a ordenha. Não force a entrada das vacas na sala de ordenha, respeite a ordem definida por elas próprias. Respeite as preferências e a individualidade de cada animal na hora de escolher o local para ser ordenhada.

\section{-Sala de Espera}

A sala de espera é a infra-estrutura de recepção dos animais vindos da pastagem, os quais permanecem nesse local, à espera da ordenha, sem acesso à alimentação suplementar. Ela está anexa à sala de ordenha é, na maioria das fazendas, a área mais estressante para as vacas em lactação. Quando o animal é confinado no curral de espera durante 15 a $60 \mathrm{~min}$, duas ou três vezes ao dia, o estresse pode ocorrer mesmo a uma temperatura ambiente moderada (ARMSTRONG,1994).

As instalações devem oferecer conforto ao animal permitindo que ele expresse seu potencial para produção; elas devem ser construídas e 
ALVES, B.G., SILVA, T.H. e IGARASI, M.S. Manejo de ordenha. PUBVET, Londrina, V. 7, N. 6, Ed. 229, Art. 1514, Março, 2013.

planejadas com a finalidade principal de reduzir a ação dos agentes estressores que podem causar efeitos indesejáveis aos animais. As variáveis ambientais são controladas com diferentes materiais de construção, dimensionamento do espaço físico, densidade e sistema de climatização (NÄÄS \& SOUZA, 2003).

As alternativas para manter ou melhorar o desempenho e o bem-estar dos animais em climas quentes, necessariamente, envolvem a metabolização de energia e sua liberação para o ambiente, por meio dos processos de trocas térmicas entre o animal e o ambiente (INGRAM, 1978; JOHNSON, 1987).

O principal fator a ser considerado para se garantir o conforto ao animal em países tropicais e subtropicais é o de minimizar os efeitos do estresse térmico. As condições climáticas nessas regiões são um grande desafio aos produtores por alterarem os três processos vitais dos animais: a mantença, a reprodução e a produção de leite (HEAD, 1995). De acordo com Rasgdale (1961), a temperatura ótima de produção de leite depende da espécie, raça e grau de tolerância ao calor e ao frio. A raça Holandesa tem sua produção reduzida a partir de $24^{\circ} \mathrm{C}$, a Suíça e a Jersey a partir de $27^{\circ} \mathrm{C}$ e as Zebuínas acima de $32^{\circ} \mathrm{C}$.

Os efeitos do ambiente térmico sobre as respostas fisiológicas de bovinos leiteiros como a frequência respiratória (FR), temperatura retal (TR) e temperatura de pelame (TP), têm sido bastante estudados, principalmente para animais em lactação, como forma de caracterizar situações de estresse, explicando a tentativa do animal em perder o calor absorvido (AZEVEDO et al., 2005; MAIA et al., 2005; MORAIS et al., 2008).

As diferenças sazonais na produção de leite são causadas por mudanças periódicas de temperatura e umidade durante o ano e têm efeito direto na produção de leite, pela diminuição da ingestão de matéria seca e efeito indireto pela oscilação na quantidade e qualidade do alimento (BOHMANOVA ET AL., 2007). O investimento em climatização é uma alternativa viável e disponível para minimização do estresse térmico animal, sendo decisiva a orientação do capital investido, com garantia de retorno (MARTELLO, 2002). Este 
ALVES, B.G., SILVA, T.H. e IGARASI, M.S. Manejo de ordenha. PUBVET, Londrina, V. 7, N. 6, Ed. 229, Art. 1514, Março, 2013.

investimento deverá ser capaz de estimar aspectos relacionados não somente à rentabilidade, mas também, à capacidade de pagamento e tempo necessário para recuperar o capital investido (ROMANINI et al., 2002).

Segundo Ferreira et al. (2009) os bovinos se defendem do estresse térmico e recorrem a mecanismos adaptativos fisiológicos de perda de calor corporal para evitar a hipertermia. Desta forma, aumentam a frequência respiratória como mecanismo adicional à perda de calor por sudorese constituindo-se, ambos, em meios importantes de perda de calor por evaporação.

A temperatura de superfície corporal depende principalmente das condições ambientes de umidade, temperatura do ar e vento, e das condições fisiológicas, como vascularização e evaporação pelo suor. Assim, contribui para a manutenção da temperatura corporal mediante trocas de calor com o ambiente em temperaturas amenas, e sob condições de estresse pelo calor, as perdas sensíveis são diminuídas e a evaporação torna-se o principal processo de perda de calor (FERREIRA et al., 2006).

Para manuseio de animais adultos, a sala de espera deve ser de aproximadamente $2,5 \mathrm{~m}^{2}$ por animal a ser ordenhado quando o sistema é a pasto e quando é confinamento deve ser $1,8 \mathrm{~m}^{2}$ por animal. Deve haver uma margem positiva de 20 a $50 \%$ no tamanho, para que possa entrar outro lote.

Preferencialmente, o piso deve ser de concreto ou cimentado, garantindo maior durabilidade e há a necessidade de frisos para garantir apoio aos animais. Eles devem ser de 1 a 1,3cm de largura e profundidade de 1,2 a 1,8 $\mathrm{cm}$ para que com o desgaste os frisos não desapareçam. As cercas devem ser de tubos galvanizados, correntes ou réguas de madeira. $\mathrm{O}$ declive deve ser de $2 \%$ a $4 \%$ no sentido da ordenha (SMITH et al, 1998).

\subsection{SALA DE ORDENHA}

A implantação de um correto manejo de ordenha é de extrema importância para o controle de mastite independente do tamanho do rebanho 
ALVES, B.G., SILVA, T.H. e IGARASI, M.S. Manejo de ordenha. PUBVET, Londrina, V. 7, N. 6, Ed. 229, Art. 1514, Março, 2013.

ou do tipo de equipamento de ordenha. Além do objetivo de reduzir o risco de novas infecções intramamárias, o manejo de ordenha tem a função de promover um bom estímulo de ejeção do leite para que se tenha uma ordenha completa, rápida e com baixo risco de lesões aos tetos das vacas e garantir a qualidade do leite produzido na fazenda.

Os princípios que orientam um correto manejo de ordenha incluem: procedimentos de desinfecção dos tetos antes da ordenha, estimulação da ejeção do leite, extração eficiente e rápida do leite e desinfecção dos tetos após a ordenha. Estes procedimentos, quando utilizados em conjunto constituem a estratégia mais eficiente na prevenção da transmissão de agentes contagiosos e em menor escala de agentes ambientais no momento da ordenha.

Para que a ordenha de vacas leiteiras seja realizada com máxima eficácia, é necessário analisar três fatores-chaves distintos que precisam funcionar de forma harmônica: a vaca, o operador e a máquina.

\section{- A vaca}

O animal é uma máquina biológica que deve expressar todo o seu potencial quando trabalha sobre ótimas condições ambientais. Quando estas condições não são adequadas, geralmente ocorre um reflexo negativo na produtividade. O problema principal está na adaptação das raças leiteiras, de origem européia, que devido a sua alta produtividade muitas vezes sofrem problemas de alterações fisiológicas e de comportamento provocadas por estresse térmico, causando redução na produção de leite.

A produção de leite em vacas leiteiras está positivamente correlacionada à freqüência de ordenhas (KNIGHT \& DEWHURST, 1994). Quando o número de ordenhas diárias passa de duas para três vezes, a produção de leite aumenta de 6 a 25\%. Em sistemas de duplo propósito, a produção de leite em 
ALVES, B.G., SILVA, T.H. e IGARASI, M.S. Manejo de ordenha. PUBVET, Londrina, V. 7, N. 6, Ed. 229, Art. 1514, Março, 2013.

fêmeas amamentando e ordenhadas aumenta de 7 a 20\% (BAR-PELED et al., 1995).

Erdman \& Varner (1995) compilaram dados de 20 trabalhos científicos e observaram que a utilização de três ordenhas diárias provocou aumento de 3,5 kg/dia de leite, em relação a duas ordenhas. Segundo Ruas et al. (2006), a prática de duas ordenhas diárias, em vez de uma, aumenta em 24,54\% a produção de leite e a utilização de uma e duas ordenhas diárias, de forma alternada, em relação a uma de forma contínua, aumenta em 19,53\% a produção de leite.

A incidência da mastite não é influenciada pela redução do número diário de ordenhas como também o desempenho dos bezerros não é alterado pelas freqüências de amamentação.

\section{- O ordenhador}

As relações entre o homem e os animais podem ter grande impacto sobre o bem-estar de animais de fazenda, constituindo-se um aspecto da criação animal em que, com educação, é possível alcançar boas mudanças sem grandes custos, melhorando os níveis do bem-estar animal (HEMSWORTH et al., 2003).

Atualmente problemas com mão-de-obra tem sido o grande desafio a ser vencido dentro de propriedades produtoras de leite, pois não é nada fácil juntar conhecimento, motivação e habilidade para que seja formada uma característica chamada competência. Diante disso deve-se saber que é um sistema multifatorial que fará com que um funcionário desempenhe sua função dignamente, fatores estes que incluem principalmente: Auto-Realização, AutoEstima, Questões Sociais de Convívio, Segurança e Proteção, Necessidades Básicas, uma empresa leiteira que não forneça estes 5 (cinco) itens básicos aos seus funcionários, está fadada ao fracasso.

Numa pesquisa, realizada pela Clinica do Leite-ESALQ em 2007, identificaram que o item de Questões Sociais é mais de $80 \%$ preenchida 
ALVES, B.G., SILVA, T.H. e IGARASI, M.S. Manejo de ordenha. PUBVET, Londrina, V. 7, N. 6, Ed. 229, Art. 1514, Março, 2013.

somente em $58 \%$ dos funcionários de ordenha entrevistados, os outros itens não se obtiveram significância, nos mostrando deste modo a precariedade do sistema de gestão pessoal dentro das propriedades leiteiras.

O ordenhador deve sempre cuidar de sua higiene pessoal e de sua saúde, realizando exames de rotina com atenção especial para tuberculose e brucelose. A adoção de procedimentos básicos de higiene é fundamental, devendo-se lavar as mãos antes e durante as ordenhas; lavar as mãos após ir ao banheiro; manter cabelo preso e unhas cortadas e usar roupas, aventais e botas limpos. Tudo isto contribui para melhorar a saúde das vacas e a qualidade do leite (ROSA et al., 2009).

Quanto ao tratamento do ordenhador para como animal já é claro que um funcionário que fala baixo e toca a vaca sem grandes estresses ao animal além de melhorar a produção (PETERS et al., 2010), por proporcionar o bemestar das vacas, melhora a função imune, o que previne altas CCS, novas infecções e prevenção de casos crônicos de mastite (IVEMEYER et al.2011).

Segundo Seabrook (1994), vacas sob tratamento aversivo na sala de ordenha defecaram seis vezes mais que aquelas tratadas gentilmente, sugerindo ativação do sistema nervoso simpático. Em outro experimento, vacas que receberam maus tratos ao entrarem na sala de ordenha, algo que freqüentemente ocorre na prática, apresentaram redução na produção de leite em relação àquelas tratadas gentilmente (BREUER et al., 2000).

Hemsworth et al. (1995) compararam a produção leiteira de 14 propriedades leiteiras na Austrália, e sujeitaram as vacas a um simples teste de medo, medido com base na distância que as vacas mantinham do experimentador durante o teste. Além da forte correlação negativa entre a distância mantida pela vaca e a produção leiteira da propriedade, os autores concluíram que de 30 a $50 \%$ da variação na produção leiteira entre propriedades foi explicada pelo nível de medo das vacas por seres humanos.

Além de uma correlação negativa entre a freqüência de maus tratos na sala de ordenha e a produção leiteira, Hemsworth et al. (2000) encontraram forte correlação positiva com a concentração de cortisol no leite. 
ALVES, B.G., SILVA, T.H. e IGARASI, M.S. Manejo de ordenha. PUBVET, Londrina, V. 7, N. 6, Ed. 229, Art. 1514, Março, 2013.

Rushen et al. (1999) expuseram vacas sistematicamente a um tratador aversivo e a um tratador gentil. Após uma semana, realizaram a ordenha com a presença do tratador aversivo ou do tratador gentil, ou com a ausência de ambos. A presença do tratador aversivo durante a ordenha aumentou em $70 \%$ - leite residual, medido depois da ordenha após injeção intravenosa de ocitocina, que libera o leite retido nos alvéolos da glândula mamária. O leite residual foi medido porque aumenta em situações de estresse, possivelmente em decorrência da liberação de oxitocina endógena (RUSHEN ET AL., 2001, SILVEIRA et al., 2009).

Trabalhos posteriores também indicaram que vacas discriminam um tratador gentil de um aversivo (MUNKSGAARD et al., 2001; MACHADO FILHO et al., 2001).

\section{- A máquina}

A automação de atividades, na sala de ordenha, é cada vez mais comum nas propriedades leiteiras, garantindo um processo harmonioso e rápido independente do tamanho do rebanho. Ela padroniza atividades que antes eram manuais e, portanto, passíveis de erros. O objetivo de todo produtor deve ser ordenhar eficientemente cada animal, em cada ordenha, independente do tamanho do rebanho, retirando o máximo de leite, no mínimo de espaço de tempo, sem prejudicar a saúde da vaca. Essa economia de tempo é muito importante, pois favorece uma boa esgota das vacas, aumenta a capacidade da ordenha (vacas/hora) e, conseqüentemente, do sistema como um todo além de maximizar o uso da mão-de-obra.

\section{- Infra-estrutura}

As salas de ordenha podem ser de diversas formas Balde ao Pé, Circuito Fechado, Linha alta sem fosso, linha média com fosso, linha baixa com fosso. A seleção do tipo e o grau de automação do equipamento de ordenha dependem 
ALVES, B.G., SILVA, T.H. e IGARASI, M.S. Manejo de ordenha. PUBVET, Londrina, V. 7, N. 6, Ed. 229, Art. 1514, Março, 2013.

do número de vacas em lactação, custo inicial e anual (capital disponível), disponibilidade de assistência técnica e da preferência do proprietário quanto à atenção individual por vaca e à eficiência de mão-de-obra.

Segundo a Instrução Normativa no 62, a ordenha, obrigatoriamente, deve ser feita em dependência apropriada, destinada exclusivamente a esta finalidade, e localizada afastada da dependência de abrigo de arraçoamento, bem como de outras construções para alojamento de animais. Devem observar, por exemplo, as seguintes condições: Construção em alvenaria, com pé-direito, iluminação e ventilação suficientes; piso impermeável, antiderrapante, revestido de cimento ou outro material de qualidade superior, provido de canaletas de fundo côncavo; o teto deve possuir forro em material impermeável de fácil limpeza e instalação de água sob pressão, para limpeza e sanitização da dependência.

\section{-Qualidade da Água}

A qualidade da água que abastece a propriedade leiteira deve cumprir os requisito impostos pelo Regulamento da Inspeção Industrial e Sanitária de Produtos de Origem Animal - RIISPOA. Como por exemplo não deve demonstrar, na contagem global mais de 500 (quinhentos) germes por mililitro; não demonstrar no teste presuntivo para pesquisa de coliformes maior número de germes do que os fixados pelos padrões para 5 (cinco) tubos positivos na série de $10 \mathrm{ml}$ (dez mililitros) e 5 (cinco) tubos negativos nas séries de $1 \mathrm{ml}$ (um mililitro) e 0,1 (um décimo de mililitro) da amostra e a água deve ser límpida, incolor, sem cheiro e de sabor próprio agradável.

\section{- Ordenha Manual}

No Brasil ainda está presente em muitas propriedades a ordenha manual de vacas, a qual deve ser feita de maneira mais higiênica possível em que o ordenhador deve ter os cuidados citados acima para que obtenha um leite de 
ALVES, B.G., SILVA, T.H. e IGARASI, M.S. Manejo de ordenha. PUBVET, Londrina, V. 7, N. 6, Ed. 229, Art. 1514, Março, 2013.

qualidade. O local deve ser limpo, seco e arejado, distante de esterqueiras, chiqueiros ou galinheiros. Diariamente deve-se lavar e desinfetar os baldes utilizados com sanitizantes $(1 \mathrm{ml}$ de hipoclorito de sódio +1 litro de água fervida ou filtrada) (EMBRAPA GADO DE LEITE). A rotina de ordenha deve ser seguida da mesma forma como na ordenha mecânica, abordada a seguir.

\section{- Rotina de ordenha}

A rotina de ordenha "adequada" é aquela em que um equipamento limpo é acoplado às tetas limpas e secas, com mínima entrada de ar, e retirado, também sem entrada de ar na tubulação, quando o fluxo de leite acaba. Para tanto, as vacas deveriam chegar à sala de ordenha com os tetos limpos, o que é conseguido se estiverem alojadas em locais secos.

\section{- Pré-Lavagem dos Tetos}

Nos casos em que os tetos estiverem muito sujos é necessário que sejam lavados, entretanto o jato de água deve ser direcionado somente para o teto, evitando que contaminantes presentes no úbere escorram para o óstio do teto, contaminando o leite.

Diversos métodos diferentes para avaliar a higiene do úbere foram descritos (COOK, 2002; SCHREINER \& RUEGG, 2003; RENEAU et al., 2005) e alguns foram usados para provar que a higiene ineficaz resulta em problemas de saúde do úbere. Reneau et al (2005) criaram um sistema de avaliação do grau de contaminação por matéria orgânica em áreas diferentes utilizando uma escala de 5 pontos (Figura 2). 
ALVES, B.G., SILVA, T.H. e IGARASI, M.S. Manejo de ordenha. PUBVET, Londrina, V. 7, N. 6, Ed. 229, Art. 1514, Março, 2013.
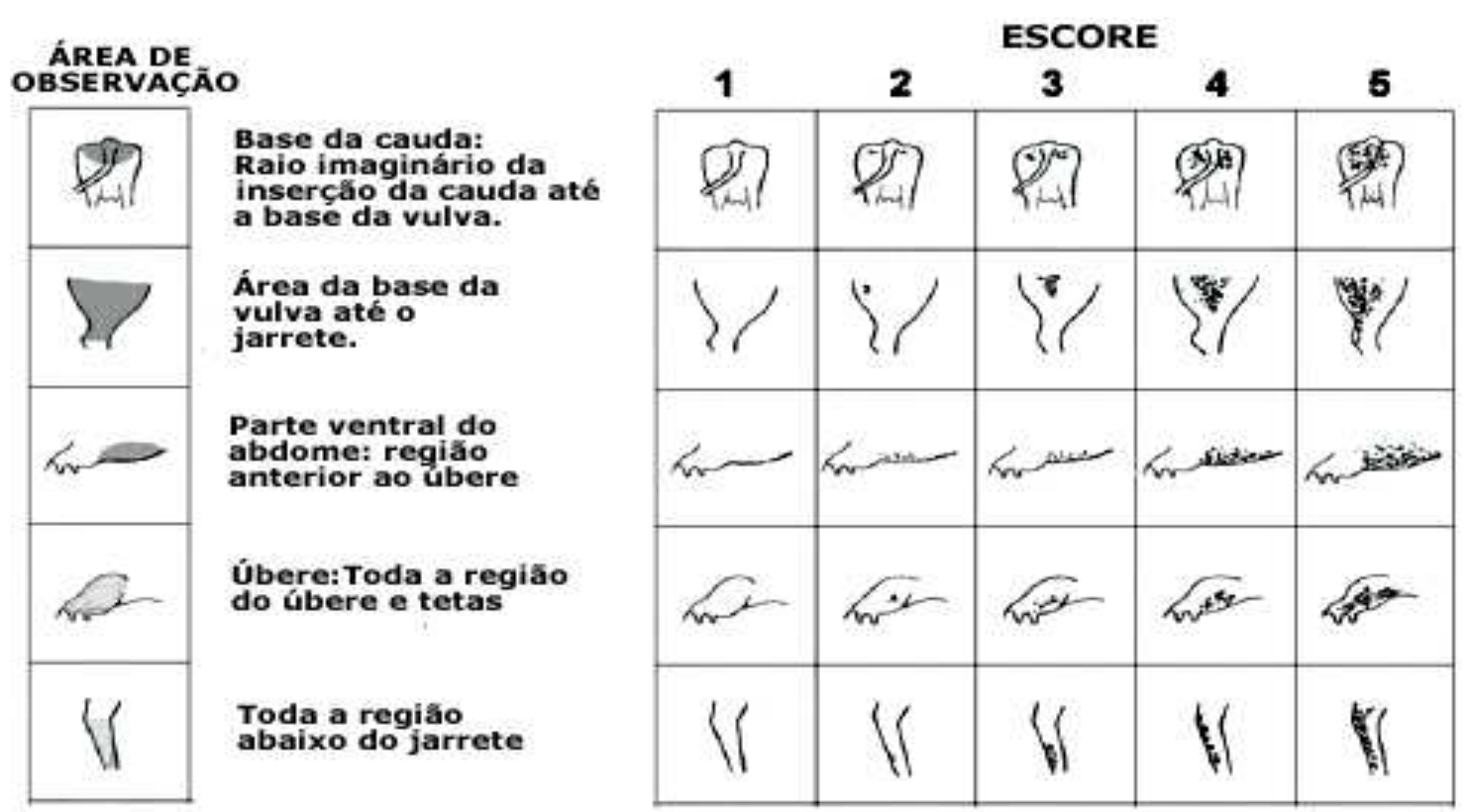

Figura 2. Sistema de avaliação da higiene da vaca em 5 diferentes áreas numa escala de 5 pontos. Fonte: Reneau et al (2005).

A avaliação do nível de contaminação de fezes no rebanho e o seu mecanismo de transferência ao úbere é uma ferramenta muito importante que pode ser usada na propriedade leiteira. Com este conhecimento, é possível realizar um estudo para que a forma e a fonte de contaminação sejam extintas ou amenizadas dentro do sistema.

O procedimento de limpeza dos tetos é feita com as mãos, devidamente enluvadas com luvas de procedimento, para retirar o excesso de sujeira. Se os tetos estiverem com lama deve-se usar o desinfetante para que facilite a retirada da mesma. A maneira de limpar é massageando as laterais e as pontas de cada teto, isso feito, faz-se o teste da caneca retirando os 3 primeiro jatos de leite, pois diminuirá a carga de bactérias, estimulará a decida do leite e detectará grumos de mastite clínica. (SANTOS E FONSECA, 2007).

\section{- Pré-dipping}

Pré-dipping é um procedimento de desinfecção dos tetos antes da ordenha e tem como objetivo a prevenção da mastite ambiental. Este consiste na 
ALVES, B.G., SILVA, T.H. e IGARASI, M.S. Manejo de ordenha. PUBVET, Londrina, V. 7, N. 6, Ed. 229, Art. 1514, Março, 2013.

imersão dos tetos em solução desinfetante, podendo ser utilizada solução de iodo $(0,25 \%)$, solução de clorexidine (de 0,25 a $0,5 \%$ ) ou ainda de cloro $(0,2 \%)$.

Os princípios ativos mais utilizados para desinfecção dos tetos são o iodo, clorexidina, ácido sulfônico, cloro, peróxidos, lauricidina e ácido cloroso. Com objetivo de minimizar a irritação e condicionar a pele dos tetos, são utilizadas algumas bases e emolientes na formulação desses germicidas, como a glicerina, lanolina, propilenoglicol, sorbitol, óleos vegetais, minerais e colágeno (SANTOS \& FONSECA, 2006).

Segundo Pales et al. (2005), este processo diminui a incidência de microrganismos no leite, além de representar até $50 \%$ de redução na taxa de novas infecções de mastites ambientais de acordo com Müller (2002).

Feita a limpeza dos tetos deverá ser feita a aplicação da solução de prédipping pelos tetos que ficam mais distantes para os mais próximos. Depois da aplicação deixe a solução agir por 30 segundos e então, seque os tetos com um papel toalha para cada (Figura 3 ).

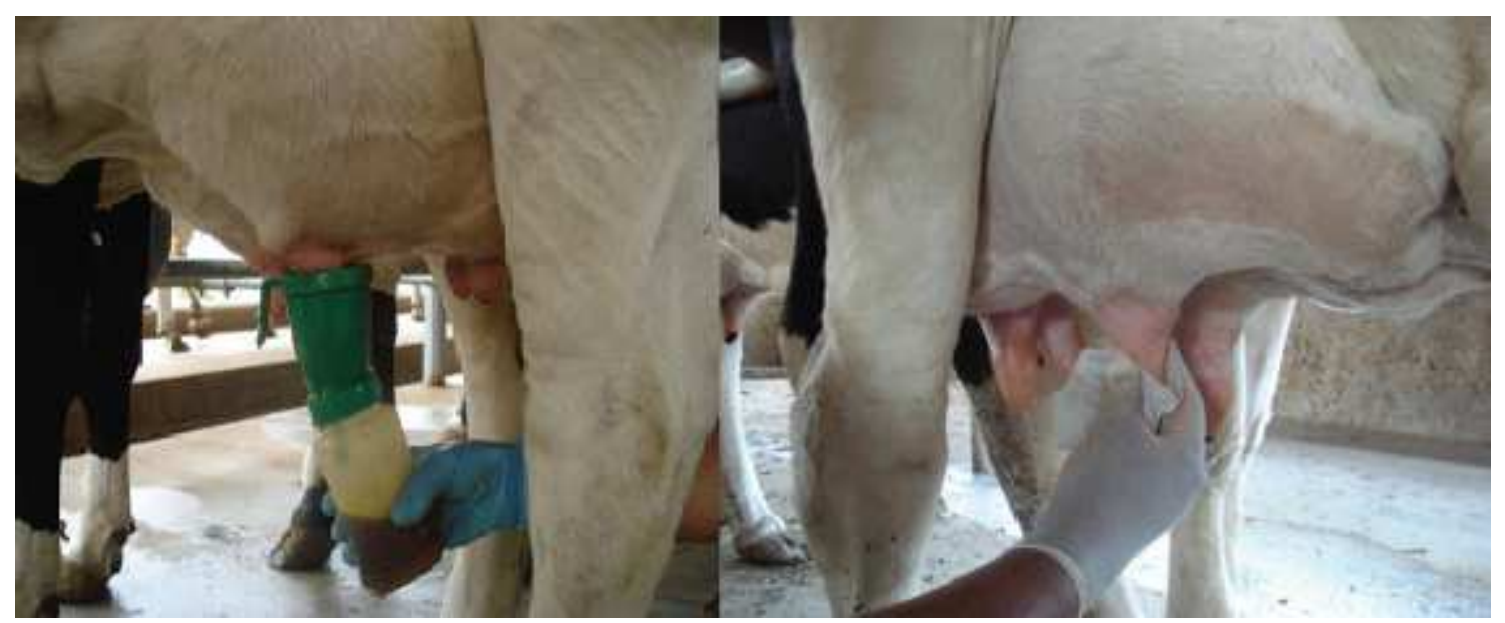

Figura 3. Realização do pré-dipping e secagem dos tetos.

Fonte: Boas práticas de Manejo Ordenha; Rosa, M.S. Funep 2009

Muitos acharão que atrasará o tempo de ordenha total realizando estes procedimentos, entretanto Watters et al., 2012, num estudo, dizem que o 
ALVES, B.G., SILVA, T.H. e IGARASI, M.S. Manejo de ordenha. PUBVET, Londrina, V. 7, N. 6, Ed. 229, Art. 1514, Março, 2013.

tempo de ordenha total diminui por aumentar o fluxo de ejeção de leite, quando vacas no final de lactação são estimuladas por mais de 60 segundos.

\section{- Colocação das teteiras}

O ideal é que as teteiras sejam mantidas "estranguladas" para baixo (em forma de "Z") até o momento da colocação, evitando a entrada de ar e possíveis contaminações conforme mencionado por Machado e Cassoli (2009).

\section{- Pós-dipping}

O pós-dipping tem o objetivo de eliminar os microrganismos presentes na pele do tetos após o término da ordenha, sendo medida eficaz na prevenção de novos casos de mastite causados por microrganismos contagiosos, como Staphylococcus aureus e Streptococcus agalactiae.

No pós-dipping a imersão dos tetos deve ser feita em solução anti-séptica depois da ordenha (FAGUNDES; OLIVEIRA, 2004). Essa é considerada uma medida prática, econômica e eficaz para o controle da mastite, reduzindo mais de $50 \%$ das novas infecções intramamárias durante a lactação.

Um dos produtos utilizados para este procedimento é a solução à base de iodo entre $0,5 \%$ e $1 \%$ associados com glicerina. As soluções à base de clorexidine a 0,5\% também são usadas (SILVA, 2003; COELHO et al., 2003) (Figura 4). 
ALVES, B.G., SILVA, T.H. e IGARASI, M.S. Manejo de ordenha. PUBVET, Londrina, V. 7, N. 6, Ed. 229, Art. 1514, Março, 2013.

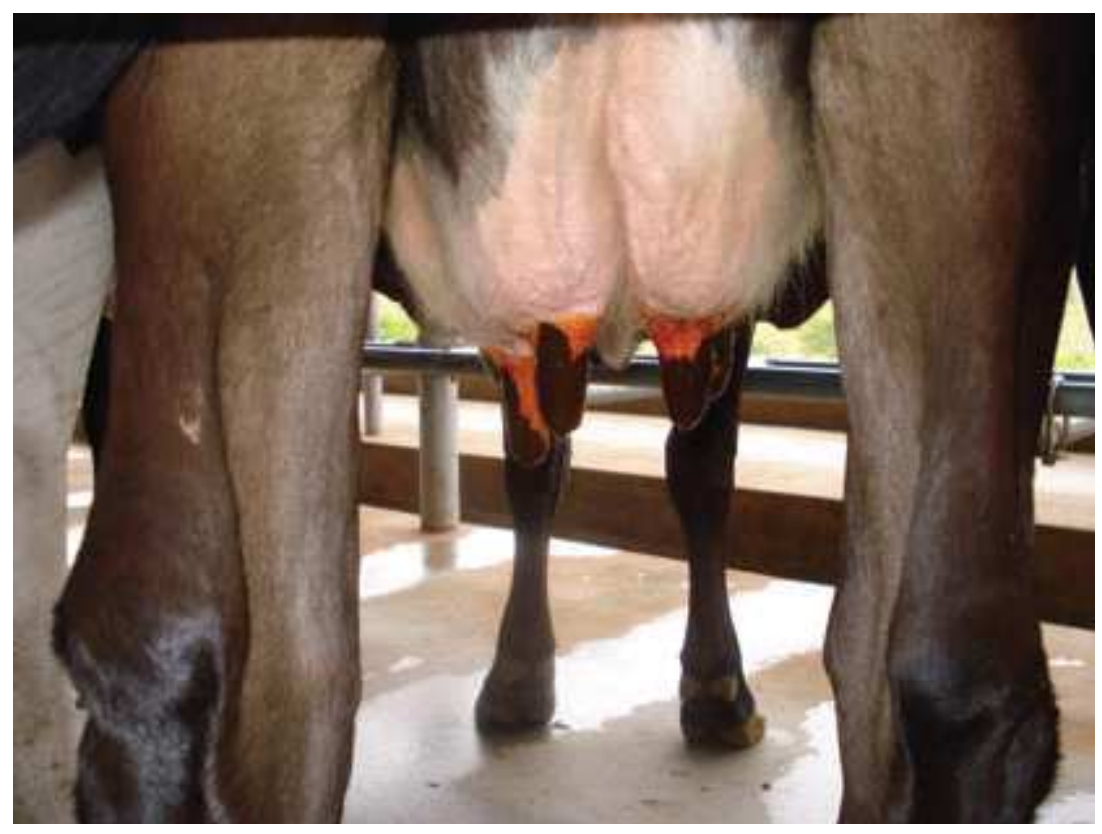

Figura 4. Tetos cobertos com solução de iodo.

Fonte: Boas práticas de Manejo Ordenha; Rosa, M.S. Funep 2009

\section{- Limpeza dos equipamentos de ordenha}

A limpeza do equipamento é também muito importante assim como o manejo e higiene da ordenha, sendo fundamental para a qualidade do leite. Inicialmente deve-se desacoplar a unidade do tanque resfriador e deixar escoar todo o leite que ainda resta na tubulação. Em seguida deve ser feita a limpeza externa das teteiras com água e sabão. Após isso feito acopla-se as teteiras na linha de limpeza e fecha-se as válvulas de limpeza (SANTOS E FONSECA, 2007)

As principais etapas de limpeza do equipamento constituem-se de enxágüe com água morna com temperatura entre 38 a $55^{\circ} \mathrm{C}$ (se for menos que $38^{\circ} \mathrm{C}$ solidifica as gorduras, e se for mais de $55^{\circ} \mathrm{C}$ desnatura as proteínas) para remover os resíduos de leite solúveis em água Essa temperatura promoverá um leve aquecimento do sistema que ajudará nos procedimentos posteriores. $\mathrm{O}$ volume de água depende de cada fabricante mas de 3 a 6 litros de água por minuto deve circular em cada unidade de ordenha durante a limpeza (SANTOS E FONSECA, 2007). 
ALVES, B.G., SILVA, T.H. e IGARASI, M.S. Manejo de ordenha. PUBVET, Londrina, V. 7, N. 6, Ed. 229, Art. 1514, Março, 2013.

Feito o enxágüe inicial faz-se o enxágüe com água e detergente alcalino clorado com temperatura inicial de $70^{\circ} \mathrm{C}$, para remover a gordura e a proteína do leite que estão encrostadas na tubulação, e no final do ciclo não deve ser menos do que $40^{\circ} \mathrm{C}$. O ciclo deve durar cerca de 10 minutos (SANTOS E FONSECA, 2007).

Enxágüe com detergente ácido é feito para retirar os minerais vindos do leite e da água. A água pode ser fria e esse procedimento deve ser feito no mínimo duas vezes por semana (SANTOS E FONSECA, 2007).

Após as lavagens alcalina e ácida deve ser feita a sanitização para a próxima ordenha (MÜLLER, 2002) em que geralmente usam-se produtos à base de cloro. Na ordenha manual, os baldes e os utensílios deverão ser lavados com água corrente e detergente. Depois de lavados, devem ser virados para baixo em local limpo, para secarem naturalmente. (Figura 5)

Em relação à instalação e manutenção do equipamento devem ser obedecidas as normas internacionais (ISSO 5707-3 A) dando ênfase ao dimensionamento da bomba de vácuo, nível de vácuo, pulsação e troca de teteiras.

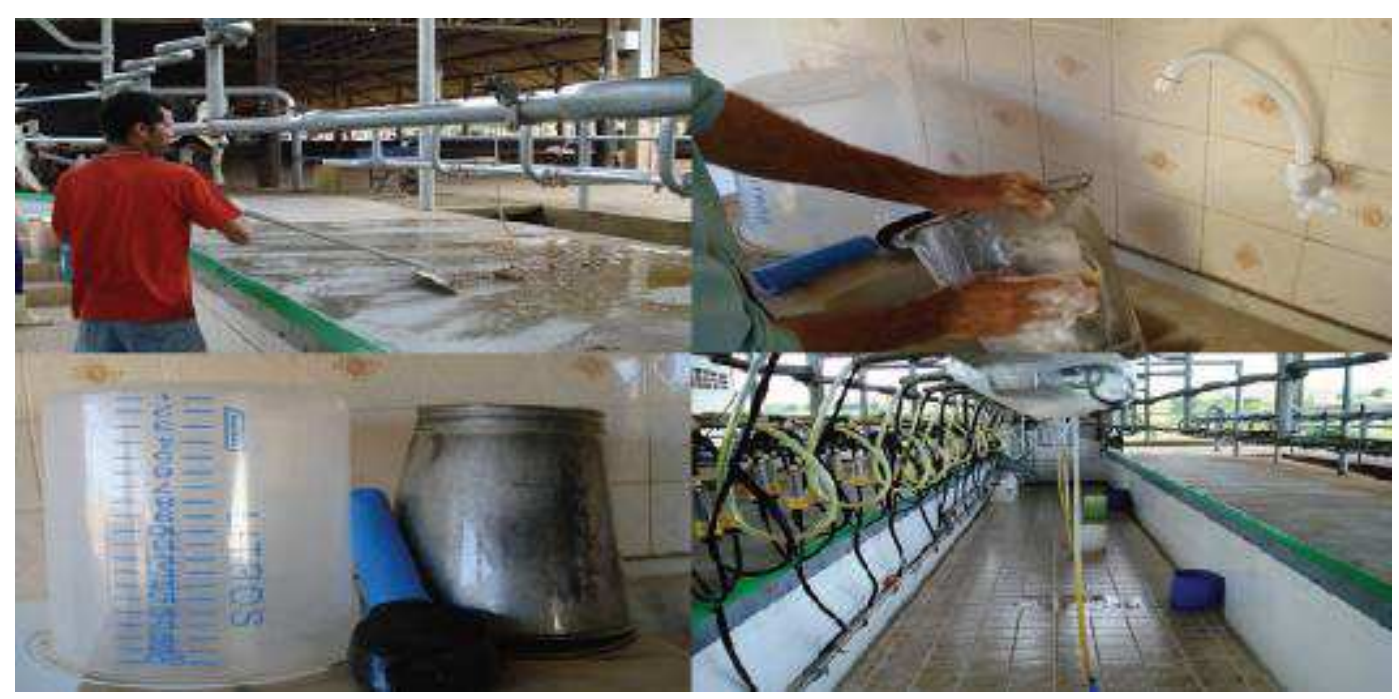

Figura 5. Limpeza e desinfecção da ordenha mecânica e manual Fonte: Boas práticas de Manejo Ordenha; Rosa, M.S. Funep 2009 
ALVES, B.G., SILVA, T.H. e IGARASI, M.S. Manejo de ordenha. PUBVET, Londrina, V. 7, N. 6, Ed. 229, Art. 1514, Março, 2013.

\section{- Limpeza do tanque de expansão}

Enxaguar com água morna ( 38 a $43^{\circ} \mathrm{C}$ ); preparar cerca de 5 a 10 litros de solção de detergente alcalino clorado a 49 a $54^{\circ} \mathrm{C}$, e esfregar bem todo o tanque. Antes de usar o tanque deve-se usar uma solução sanitizante (a base de cloro) para reduzir contaminação e deixar drenar bem a solução para quando o tanque for receber o leite. Lavagens com detergente ácido são interessantes para evitar acúmulo de minerais (pedra) no leite (SANTOS E FONSECA, 2007).

\section{- Mastite}

A mastite é a inflamação do tecido glandular que, independentemente do agente causador, irá induzir à modificação patológica do tecido. As alterações mais importantes, observadas no leite, é a descoloração, o aparecimento de coágulos e a presença de grande número de leucócitos. A glândula mamária apresenta aumento de volume, elevação da temperatura, e endurecimento em muitos casos clínicos. Entretando, segundo Radostits (2000), se há grande proporção de glândulas acometidas, a identificação da doença pela palpação ou exame visual é comprometida.

A mastite clínica apresenta sintomas tais como aumento da temperatura, edema, grumos, pus, dentre quaisquer alteração visualmente detectável no leite. Já a mastite subclínica não apresenta sintomatologia e as alterações do leite somente podem ser detectáveis pelo teste CMT, abordado posteriormente.

Esta doença pode ser subdividida quanto à forma de contágio, em contagiosa e ambiental. A mastite contagiosa é causada por microorganismos que estão no úbere e são facilmente transmitidos para outro animal pelas mãos do ordenhador ou pelas teteiras, cabendo assim a necessidade da segregação das vacas com mastites na linha de ordenha, colocando-as por último. Neste caso as bactérias mais envolvidas são Streptococcus agalactiae, Corynebacterium bovis, Staphylococcus aureus e Mycoplasma spp.

A forma ambiental é causada por microrganismos presentes no ambiente (solo, currais etc), com maior freqüência nos períodos quentes e úmidos do 
ALVES, B.G., SILVA, T.H. e IGARASI, M.S. Manejo de ordenha. PUBVET, Londrina, V. 7, N. 6, Ed. 229, Art. 1514, Março, 2013.

ano. Este tipo da doença é mais facilmente transmitido ao final da ordenha quando o animal deita sobre o solo contaminado, enquanto o orifício do teto ainda se encontra aberto. Os patógenos ambientais causadores de mastite clínica incluem a espécie de estreptococos (S. uberis e o S. dysgalactiae são os mais prevalentes, e o menos prevalente é o $\mathrm{S}$. equinus). No grupo dos coliformes ambientais, encontram-se as bactérias Gram-negativas (Escherichia coli, Klebsiella spp., Citrobacter spp., Enterobacter spp., E. faecalis e E. faecium). Existem também patógenos incomuns, podendo causar mastite grave, mas acomete poucas vacas e esporadicamente; os de origem fúngica (ex. Trichosporon spp.) e viral (PINTO et al, 2001; RADOSTITS, 2000).

Para o diagnóstico da mastite, seja ela clínica ou subclínica alguns testes podem ser executáveis na rotina da ordenha, para tomada de decisões; tratamento e descarte de vacas.

O teste da caneca telada, ou de fundo preto, é utilizado para o diagnóstico da mastite clínica em todas as vacas e em todas as ordenhas (Figura 6). Para tanto, após a lavagem dos tetos retira-se os primeiros três jatos de cada teto e faz-se a avaliação visual da presença de grumos de pus, sangue ou qualquer coloração alterada. Caso se confirme a presença de grumos, o animal deve ser retirado desta linha de ordenha para ser ordenhado ao final dos animais sadios.

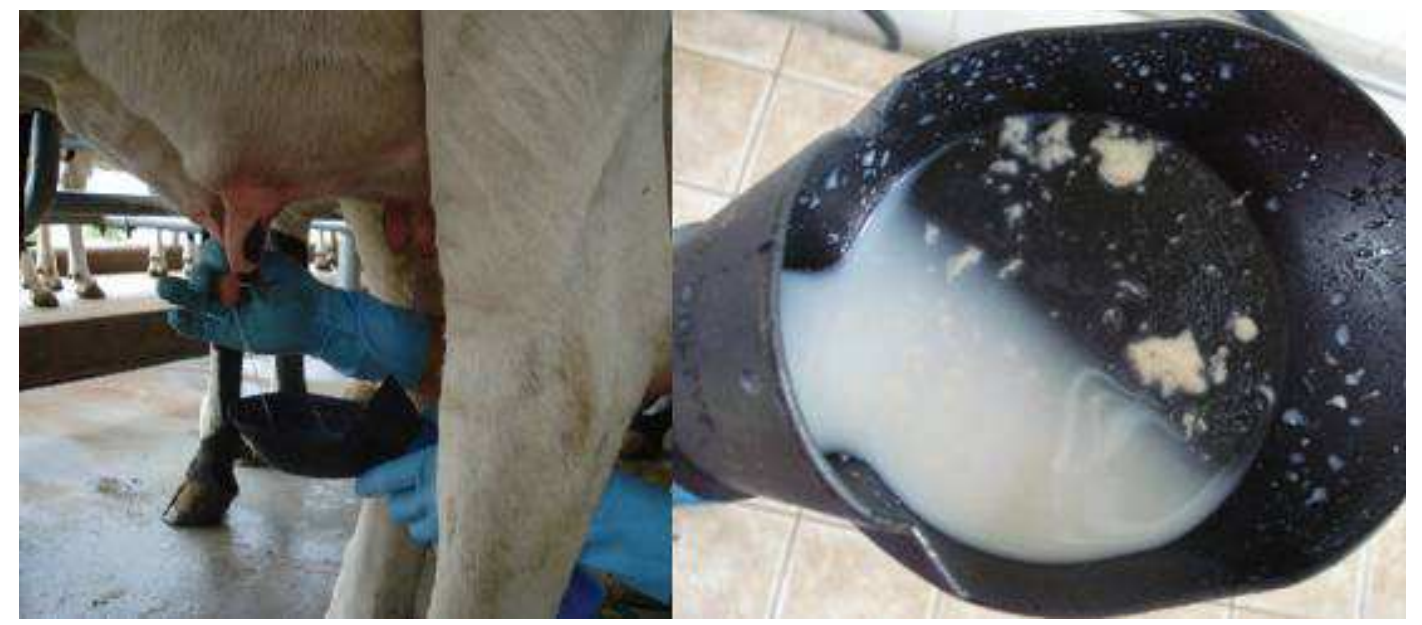

Figura 6. Uso da caneca de fundo preto e presença de grumos Fonte: Boas práticas de Manejo Ordenha; Rosa, M.S. Funep 2009 
ALVES, B.G., SILVA, T.H. e IGARASI, M.S. Manejo de ordenha. PUBVET, Londrina, V. 7, N. 6, Ed. 229, Art. 1514, Março, 2013.

O diagnóstico da mastite subclínica é detectado pelos testes indiretos, realizados no leite das vacas, são o California Mastitis Test (CMT) e CCS (contagem de células somáticas no leite do tanque de resfriamento), usando contadores eletrônicos mensuram anticorpos, enzimas associadas a células e 0 aumento da condutividade elétrica do leite. O CMT estima o conteúdo de células somáticas no leite e é interpretado subjetivamente, estabelecendo-se escores que, na maioria dos casos, variam de 1 a 5 . O escore 1 indica uma reação completamente negativa e os de 2-5 indicam graus crescentes de resposta inflamatória do úbere, sendo normalmente considerados como indicativos de mastite subclínica (RADOSTITS, 2000) (Figura 7)

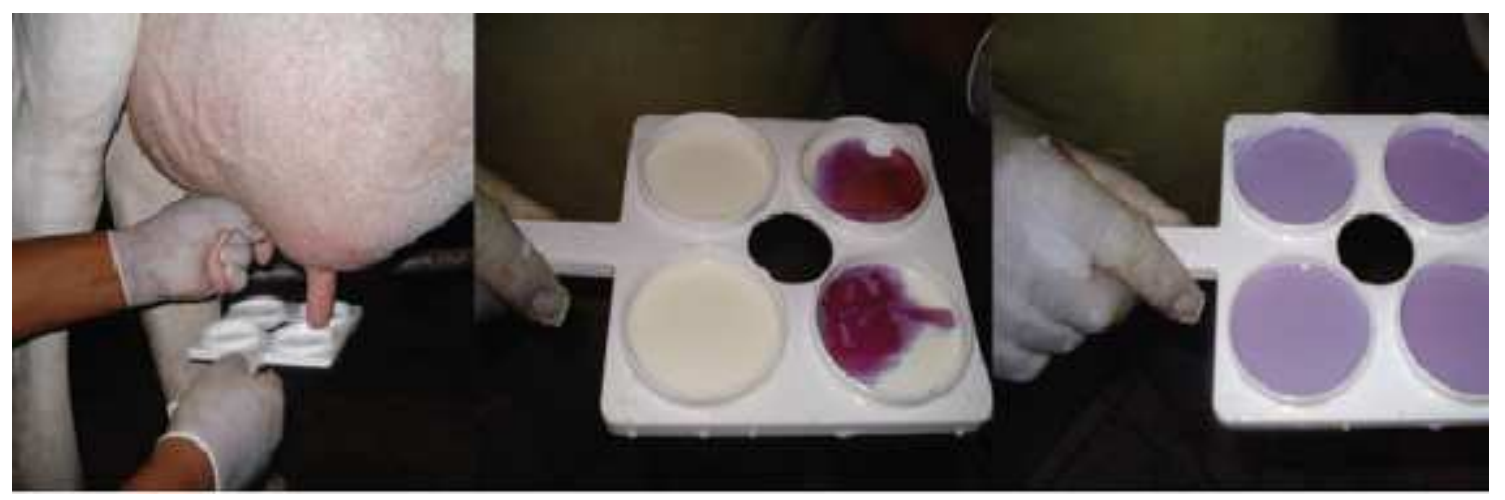

Figura 7. Seqüência de realização do CMT

Fonte: Boas práticas de Manejo Ordenha; Rosa, M.S. Funep 2009

O teste de CCS também pode ser um indicador da mastite. Segundo Philpot e Nickerson (2002) há relação do teste de CMT com o teste de CCS como pode se observar na tabela 2 .

O principal controle da mastite é através da prevenção de novas infecções. De acordo com Philpot (1997) poucos animais eliminam a infecção espontaneamente, necessitanto da terapia com medicamentos ou descarte de animais.

A antibioticoterapia para a mastite deve levar em conta o custo econômico do tratamento, se o fato compensará na produção de leite e quantos quartos estão infectados. A terapia mais indicada no controle das 
ALVES, B.G., SILVA, T.H. e IGARASI, M.S. Manejo de ordenha. PUBVET, Londrina, V. 7, N. 6, Ed. 229, Art. 1514, Março, 2013.

mastites é a infusão intramamária de um antibiótico, acompanhada pelo esgotamento freqüente e total do quarto infectado.

Tabela 2. Associação da contagem de células somáticas com o teste CMT.

\begin{tabular}{|l|l|}
\hline Grau CMT & CCS (por ml de leite) \\
\hline Negativo & 100.000 \\
\hline Traço (falso positivo) & 300.000 \\
\hline Fracamente positivo (+) & 900.000 \\
\hline Positivo (++) & 2.700 .000 \\
\hline Fortemente positivo (+++) & 8.100 .000 \\
\hline
\end{tabular}

Adaptado de Philpot e Nickerson (2002)

O ideal para o tratamento da mastite clínica na vaca lactante é fazer a cultura do leite e sensibilidade antimicrobiana. Quanto à mastite subclínica o ideal é que se faça a secagem das vacas com posterior infusão intramamária de antibióticos de longa duração próprios para vacas secas. Deve ser respeitado um período de carência para a comercialização do leite dos animais tratados com antibióticos, para evitar resíduos (RADOSTITS, 2000).

O manejo adequado na ordenha, instalações corretas, manejo da vaca seca, terapia apropriada à mastite durante a lactação, descarte das vacas com infecções crônicas, manutenção do ambiente e estabelecimento de metas para o estado de saúde do úbere são medidas que devem ser tomadas para prevenir a mastite e melhorar a produtividade (RADOSTITS, 2000).

\subsection{SAÍDA DOS ANIMAIS DA ORDENHA}

\section{- Necessidade de água}

Sabe-se que a maio procura por água pelas vacas é na saída da ordenha, pois além delas associarem ingestão de água com alimentação também 
ALVES, B.G., SILVA, T.H. e IGARASI, M.S. Manejo de ordenha. PUBVET, Londrina, V. 7, N. 6, Ed. 229, Art. 1514, Março, 2013.

associam com ordenha e geralmente acontece nas horas mais claras do dia, em que podemos associar que seja nas horas mais quentes do dia (PERISSINOTTO et al, 2005). Portanto é clara a necessidade de bebedouros nestes locais sabendo-se que o leite tem cerca de $88 \%$ de água. Segundo Degaspari \& Piekarski (1998) vacas em lactação necessitam de 4 a $5 \mathrm{~L}$ de água por kilo de leite produzido.

As medidas de bebedouros utilizadas são de 0,6 $\mathrm{m}$ lineares por vaca de um lado da ordenha. Por exemplo, em uma ordenha $8 \times 2$, necessita-se 4,8 m de bebedouro na sala de espera e na saída da ordenha.

\section{- Manejo}

Após a ordenha, é necessário que as vacas permaneçam o máximo de tempo em pé, pois sabe-se que os óstios dos tetos demoram cerca de 2 horas para fecharem totalmente (KEHRLI e HARP, 2001). Para isso, faz-se a oferta de alimentos frescos e de alta qualidade logo após a ordenha a fim de diminuir esta possibilidade de infeç̧ão por manter os animais em pé se alimentando. Além disso, há o condicionamento dos animais na entrada e saída da ordenha, facilitando a rotina de manejo.

\section{CONCLUSÃO}

Atualmente o principal foco a ser dado dentro de propriedades leiteiras é quanto a gestão de pessoas no manejo de ordenha, pois para se obter um leite de qualidade que é o produto final da empresa, deve-se ter uma ordenha bem feita $e$ isso depende integralmente do bem-estar dos funcionários ali envolvidos. 


\section{REFERÊNCIAS}

TRONG, D. V. Heat stress interaction with shade and cooling. Journal of Dairy Science, v.77, n.8, p.2044-2050, 1994.

AZEVEDO, M.; PIRES, M. F. A.; SATURNino, H. M.; LANA, A. M. Q.; SAMPAiO, I. B. M.; MONTEIRO, J. B. N.; MORATO, L. E. Estimativas de níveis críticos superiores do índice de temperatura e umidade para vacas leiteiras 1/2, 3/4 e 7/8 Holandês-Zebú, em lactação.

Revista Brasileira de Zootecnia, v.34, n.6, p.2000-2008, 2005.

BAR-PELED, U.; MALTZ, E.; BRUCKENTAL, I. et al. Relationship between frequent milking or suckling in early lactation and milk production of high producing dairy cows. Journal of Dairy Science, v.78, n.12, p.2726-2736, 1995.

BOHMANOVA, J.; MISZTAL, I.; COLET, J. B. Temperature-humidity indices as indicators of milk production losses due to heat stress. Journal of Dairy Science, v.90, n.4, p.1947-1956, 2007.

BREUER, K.; HEMSWORTH, P.; BARNETT, J. et al. Behavioural response to humans and the productivity of commercial dairy cows. Applied Animal Behaviour Science, v.66, n.4, p.273-288, 2000.

BRUCKMAIER R. M.; ROTHENANGER, E.; BLUM, J. W. Measurement of mammary gland cistern and determinations of the cistern milk fraction in dairy cows. Milchwissenschaft v.49, p.5436, 1994.

CHILLIARD, Y.; BONNET, M.; DELAVAUD, C.; FAULCONNIER, Y.; LEROUX, C.; DJIANE, J.; BOCQUIER, F. Leptin in ruminants. Gene expression in adipose tissue and mammary gland, and regulation of plasma concentration. Domestic Animal Endocrinology v.21, p.271-95, 2001.

COELHO, S. G. Glândula Mamária. Belo Horizonte: Escola de Veterinária da Criação de bovinos. 7 ed. Belo Horizonte: Consultoria Veterinária e Publicações, 2003.

DEGASPARI, S. A. R.; PIEKARSKI, P. R. B. Bovinocultura leiteira: Planejamento, Manejo e instalações. Curitiba: 1998. 429p.

COOK, C. Teat preparation - remove dirt, reduce the risks. In: THE BRITTISH MASTITIS CONFERENCE. Proceedings.. Brockworth. 51-57., 2002.

ERDMAN, R.A.; VARNER, M. Fixed yield responses to increased milking frequency. Journal of Dairy Science, v.78, n.5, p.1999-2003, 1995.

FAGUNDES, H.; OLIVEIRA, C.A.F. Infecções intramamárias causadas por Staphylococcus aureus e suas implicações em saúde pública. Ciência Rural, Santa Maria. v. 34, n.4, p. 13151320, 2004.

FERREIRA, F.; CAMPOS, W. E.; CARVALHO, M. F.; PIRES, M. L.; MARTINEZ, M. V. G. B.; SILVA, R. S.; VERNEQUES, P. F. Taxa de sudação e parâmetros histológicos de bovinos submetidos ao estresse calórico. Arquivo Brasileiro de Medicina Veterinária e Zootecnia, v.61, n.4, p.763-768, 2009.

FERREIRA, F.; PIRES, M. F. A.; MARTINeZ, M. L.; COELHO, S. G.; CARVAlHO, A. U.; FERREIRA, P. M.; FACURY FILHO, E. J.; CAMPOS, W. E. Parâmetros fisiológicos de bovinos cruzados submetidos ao estresse calórico. Arquivo Brasileiro de Medicina Veterinária e Zootecnia, v.58, n.5, p.732-738, 2006. 
HEAD, H. H. Management of dairy cattle in tropical and subtropical environments. In: CONGRESSO BRASILEIRO DE BIOMETEOROLOGIA, 2., 1995, Jaboticabal. Anais... Jaboticabal: SBBiomet, p.26-68. 1995.

HEMSWORTH, P. H. Human-animal interactions in livestock production. Applied Animal Behaviour Science, v.81, p.185-198, 2003.

HEMSWORTH, P. H.; BREUER, K.; BARNETT, J. L. et al. Behavioural response to humans and the productivity of commercial dairy cows. In: INTERNATIONAL CONGRESS OF THE INTERNATIONAL SOCIETY FOR APPLIED ETHOLOGY, 29., 1995, Guelph. Proceedings... Guelph: 1995. p.175-176.

HEMSWORTH, P. H.; COLEMAN, G. J.; BARNETT, J. L. et al. Relationships between humananimal interactions and productivity of commercial dairy cows. Journal of Animal Science, v.78, p.2821-2831, 2000.

INGRAM, D.L. Thermoregulatory behavior in pigs. Proceddings. In: WORLD CONGRESS ETHOLOGY APPLIED ZOOTECHNY, 1., 1978, Madrid. Proceedings... Madrid: 1978. p.137-141.

IVEMEYER, S; KNIERIM, U; WAIBLINGER, S. Effect of human-animal relationship and management on udder health in Swiss dairy herds. Journal of Dairy Science v.94, p.58905902. 2011

JOHNSON, K.G. Shading behaviour of sheep: preliminary studies of its relation to thermoregulation, feed and water intakes, and metabolic rates. Australian Journal Research, v.38, n.4, p.587-596, 1987.

KEHRLI, M.E.; HARP, J.A. Immunity in the mammary gland. Veterinary Clinics of North America: Food Animal Practice, v.17, n3, p.495-516, 2001.

KNIGHT, C.H.; DEWHURST, R.J. Once daily milking of dairy cows: relationship between yield loss and cisternal milk storage. Journal of Dairy Research, v.61, n.4, p.441-449, 1994.

LAMOTE I, MEYER E, MASSART-LE“EN AM, BURVENICH C. Sex steroids and growth factors in the regulation of mammary gland proliferation, differentiation, and involution. Steroids, v.69, p.145-59, 2004.

MACHADO FILHO, L.C.P.; YUNES, M.C.; HÖTZEL, M.J. Is there a relationship between fear of humans and social rank in Holstein cows? In: INTERNATIONAL CONGRESS OF THE ISAE, 35., 2001, Davis. Proceedings... Davis: International Society for Applied Ethology, 2001. p.65.

MACHADO, P.F; CASSOLI, L.D. Prevenção e tratamento da mastite. Cotia: ScheringPlough. 2009.

MAIA, A. S. C.; SILVA, R. G.; LOUREIRO, C. M. B. Sensible and latent heat loss from the body surface of holstein cow in a tropical environment. International Journal of Biometeorology, v.50, p.17-22, 2005.

MARTELLO, L. S. Diferentes recursos de climatização e sua influência na produção de leite, na termorregulação dos animais e no investimento das instalações.2002. 67p. Tese Mestrado Universidade de São Paulo Pirassununga, 2002.

MORAIS D. A. E. F.; MAIA, A. S. C.; SILVA, R. G.; VASCONCELOS, A. M.; LIMA, P. O.; GUILHERMINO, M. M. Variação anual de hormônios tireoideanos e características termorreguladoras de vacas leiteiras em ambiente quente. Revista Brasileira de Zootecnia, v.37, n.3, p.538-545, 2008. 
MÜLLER, E.E. Qualidade do leite, células somáticas e prevenção da mastite. In: SANTOS, G.T.; JOBIM, C.C.; DAMASCENO, J.C. Sul-Leite: Simpósio sobre sustentabilidade de pecuária leiteira na região sul do Brasil, Anais... Maringá: UEM/CCA/DZO- NUPEL, p. 206 - 217, 2002

MUNKSGAARD, L.; DEPASSILLE, A.M.; RUSHEN, J. et al. Dairy cows' fear of people: social learning, milk yield and behaviour at milking. Applied Animal Behaviour Science, v.73, p.15-26, 2001.

NÄÄS, I. A.; SOUZA, S. R. L. Desafios para a produção de leite nos trópicos - conforto térmico. In: ZOOTEC, 2003, Uberaba. Anais... Uberaba: FAZU, 2003. p.64-74

PALES, A. P. A importância da contagem de células somáticas e contagem bacteriana total para a melhoria da qualidade do leite no brasil. Revista Eletrônica Faculdade Montes Belos, v. 1, n. 2, p. 162-173, 2005.

PERISSINOTTO, MAURÍCIO ; MOURA, DANIELLA J. DE ; SILVA, IRAN J. O. DA ; MATARAZZO, SORAIA V. Influência do ambiente na ingestão de água por vacas leiteiras. Revista Brasileira de Engenharia Agrícola e Ambiental, v.9, p.289-294, 2005

PETERS, M. D. P. ; BARBOSA SILVEIRA, I. D. ; PINHEIRO MACHADO FILHO, L. C. ; MACHADO, A. A. ; PEREIRA, L. M. R. Manejo aversivo em bovinos leiteiros e efeitos no bem-estar, comportamento e aspectos produtivos. Arquivos de zootecnia, Vol.59(227), pp.435-442, 2010

Pinto, M. S., fARIA, J. E., MESSAGe, D., CASSini, S. T. A., PeReirA, C. S., Gioso, M. M. Efeito de extratos de própolis verde sobre bactérias patogênicas isoladas do leite de vacas com mastite. Journal: Brazilian Journal of Veterinary Research and Animal Science, 2001.

PHILPOT, N.W.; NICKERSON, S.C. Vencendo a luta contra a mastite. Piracicaba : Westfalia Surge/Westfalia Landtechnik do Brasil, 2002. 192p.

RADOSTITS, O. M., GAY, C. C., BLOOD, D. C., HINCHCLIFF, K. W. Clínica Veterinária - Um tratado de Doenças dos Bovinos, Suínos, Caprinos e Equinos. 9a ed., Rio de Janeiro: Guanabara Koogan, p. 541-629, 2000

RASGDALE, A.C. Environmental physiology with special reference to domestic animal, influence of increasing of temperature 400 to $1050 \mathrm{~F}$ on milk production in BrownSwiss cows, and on feed and water comsumption and bodywieght in Brown Swiss and Brahman cows and heifers. Missouri Agiculture Research Bulletin, n.471, 1961.

RENEAU, J. K.; SEYKORA, A.J.; HEINS, B. J.; EMDRES, M. I.; FARNSWORTH, R. J.; BEY, R. F. Association between hygiene scores and somatic cell scores in dairy cattle. Journal of the American Veterinary Medical Association, v.227, p.1297-1301.2005

ROMANINI, C. E.; NÄÄS, I. A.; MUNIZ, I. R. Análise do investimento em climatização para matrizes na maternidade e seu efeito no desempenho de leitões. In: Congresso LatinoAmericano de Suinocultura, 2002, Foz de Iguaçu. Anais... Foz de Iguaçu: 2002. CD Rom

ROSA, M.S.; COSTA, M.J.R.P.; SANT'ANNA, A.C.; MADUREIRA, A.P. Boas Prática de Manejo - Ordenha. Jaboticabal, FUNEP, 43 p. 2009.

RUAS, J.R.M.; BRANDÃO, F.Z.; FILHO, J.M.S. et al. Influência da frequência de ordenhas diárias sobre a eficiência produtiva de vacas mestiças Holandês-Zebu e o desempenho dos seus bezerros. Revista Brasileira de Zootecnia e Veterinária, v.35, p.428-434, 2006. 
RUSHEN, J.; DE PASSILLÉ, A.M.B.; MUNKSGAARD, L. Fear of people by cows and effects on milk yield, behavior, and heart rate at milking. Journal of Dairy Science, v.82, n.4, p.720727, 1999.

RUSHEN, J.; MUNKSGAARD, L.; MARNET, P.G. et al. Human contact and the effects of acute stress on cows at milking. Applied Animal Behaviour Science, v.73, p.1-14, 2001.

SANTOS, M. V.; FONSECA, L. F. L. Estratégias para Controle de Mastite e Melhoria da Qualidade do Leite. Editora Manole, Barueri. 314p. 2006

SANTOS, M.V.; FONSECA, L.F.L. (Eds) Estratégias para Controle de Mastite e Melhoria da Qualidade do Leite. São Paulo: Manole, 314p, 2007.

SCHAMS D, KOHLENBERG S, AMSELGRUBER W, BERISHA B, PFAFFL MW, SINOWATZ F. Expression and localization of oestrogen and progesterone receptors in the bovine mammary gland during development, function and involution. Journal of Endocrinology v.177, p.305$17,2003$.

SCHREINER, D. A.; RUEGG, P. L. Relationship between Udder and Leg Hygiene Scores and Subclinical mastitis. Journal of Dairy Science v.86, p.3460-3465, 2003

SEABROOK, M.F. Psychological interaction between the milker and the dairy cow. In: INTERNATIONAL DAIRY HOUSING CONFERENCE ON DAIRY SYSTEMS FOR1284 THE 21 ST CENTURY, 3., 1994, Orlando. Proceedings... Orlando: ASAE. 1994. p.49-58.

SEJRSEN, K; PURUP, S. Influence of prepubertal feeding level on milk potential of dairy heifers: a review. Journal of Animal. Science v.75, p.828-835, 1997

SILVA, N. Doença da glândula mamária: mamite/mastite. In: MARQUES, D. C. Criação de bovinos. 7 ed. Belo Horizonte: Consultoria Veterinária e Publicações. p. 435 - 451, 2003

SILVEIRA, M. C. A. C.; MACHADO FILHO, L. C. P. ; HÖTZEL, M. J. Efeito da massagem do úbere ao final da ordenha no leite residual e na ocorrência de mastite em vacas leiteiras Biotemas, v.22 (1): 129-134, 2009

SMITH, L.A., CASSEL, P.G. \& PEARSON, R.E. The effects of inbreeding on the lifetime performance of dairy cattle. Journal of dairy Science v.81, p.27-37, 1998

TUCKER, H. A. Hormones, mammary growth, and lactation: a 41-year perspective. Journal of Dairy Science, v.83, p.874-84, 2000.

TUCKER, H.A. Quantitative estimates of mammary growth during various physiological states: A review. Journal of Dairy Science., v. 70, p. 1958-1966, 1987.

WATTERS, R.D.; SCHURING, N.; ERB, H. N.; SCHUKKEN, T. H.; GALTON, D. M. The effect of premilking udder preparation on Holstein cows milked 3 times daily. Journal of Dairy Science, v. 95, Issue 3, P. 1170-1176, 2012 